Elites and Economic Development: Comparative Studies on the Political Economy of Latin American Cities 
THIS PAGE INTENTIONALLY LEFT BLANK 
Latin American Monographs, No. 41 Institute of Latin American Studies The University of Texas at Austin 
THIS PAGE INTENTIONALLY LEFT BLANK 


\section{Elites and Economic Development}

Comparative Studies on the Political Economy of Latin American Cities

by John Walton

\section{ills}

Institute of Latin American Studies

The University of Texas at Austin 
International Standard Book Number 0-292-72017-3 (cloth)

0-292-72018-1 (paper)

Library of Congress Catalog Card Number 75-620108

Copyright $\odot 1977$ by John Walton

All Rights Reserved

Manufactured in the U.S.A.

The Latin American Monographs Series

is distributed for the Institute of

Latin American Studies by:

University of Texas Press

P. O. Box 7819

Austin, Texas 78712 
To Pris,

Florence,

Ginger, and

Whitney,

family and friends 
THIS PAGE INTENTIONALLY LEFT BLANK 